\title{
Down and Dirty Lombroso's Born to Crime, the Morphoanthropology and the Ignored Human Neurophysiology: A Critical Review on s Historical Context
}

\author{
Domenico Chirchiglia ${ }^{1}$, Attilio Della Torre ${ }^{1}$, Rosa Marotta $^{2}$, Angelo Lavano ${ }^{1}$ \\ ${ }^{1}$ Department of Neurosurgery, University of Catanzaro »Magna Graecia«, Catanzaro, Italy \\ ${ }^{2}$ Department of Medical and Surgical Sciences, University of Catanzaro »Magna Graecia«, Catanzaro, Italy
}

\begin{abstract}
A B S T R A C T
Lombroso's theories, in 1800s, gave a strong shock in the international scientific community, regarding the correlation between the human morphology and its tendency to crime. They were followed, especially out of the Europe, and still are being discussed. But, in that century, they were enriched researches on human neurophysiology, which then would be further down to our time and that they denied sharply the Lombroso concepts. In short, the ignored neurophysiology, to the detriment of hypothesis which theorized the tendency to crime as an expression of the physical features of the individual, the whole body, from the face, limbs, ears, the shape of the skull. In this review, are made some critical remarks about Lombroso concepts, on 'atavism, the people considered inferior on the basis of their physical appearance, in other words what was called morphoanthropology. At the same time, this work emphasizes instead the 'importance of neurophysiological aspects of' individual tending to crime, that are the basis of abnormal acts against the society 'and that are related to the dysfunction of certain brain areas, such as the frontal cortex and limbic cortex, under the influence of genotype and environmental factors.
\end{abstract}

Key words: Behavior, Cephalometry; Anthropometry; Criminals; Neurophysiology

\section{Introduction}

The criminological sciences still represent a vast research field, particularly with regard to the neuropsychiatric aspects of the individual led to the crime. They are also developing research into the genetic constitution and, in the future, we expect news more and more interesting. In this paper we wanted to review a historical period, the 1800 s, in which there was an intense research about the neurophysiological aspects of brain functions. Eminent neuroscientists assessed, empirically and experimentally, higher brain functions such as language, behavior, memory, emotions. In short, human neurophysiology, in 1800, lived an era of great scientific fervor, and in that time another school of thought, the morphoanthropological one, was facing thanks to the Italian physician Cesare Lombroso, who correlated the tendency to crime to morphology of the criminal, especially to specific physical features. We rode in this paper the stages of that historical period, highlighting the importance of neurophysiology to under- stand the criminal acts and reviewed critically the Lombrosian theories focused on morphoanthropology.

\section{Discussion}

Down and Dirty (Brutti, sporchi e cattivi) was a movie of 1976, directed by an Italian great movie director as Ettore Scola (1931-2016), who expressed, in marvelous way, various and grotesque aspects of a small community, made up of petty thieves talented for theft, robberies, swindles, distorted sex acts, in the context of promiscuity squalid shantytown. They had in common some somatic traits, such as ugliness and filthiness. Therefore, trend to crime in these subjects was related to morphological and environmental aspects, however, the whole in an ironic sense, since it was a movie. Effectively, common sense wants that the criminal man has broadly these stigmata that are the exterior, the morphology, the face, dress in rags, look bad. This concept of criminal man, based on his 
morphological aspects, was pointed out by the Italian criminologist Cesare Lombroso (1835-1909), who theorized that crime was related to physiognomic human traits, sign of atavism, identifying the born to crime ${ }^{1}$. "The criminal is an atavistic individual that mimics the ferocious primitive instincts of mankind and animals on their person" was his memorable phrase. Lombroso's theories were based precisely to distinguish criminals from their physical aspect, especially the face ${ }^{2}$. Practically, the criminal would be a human regression in primitive subhuman, like apes and primates, and so, into a wild man, incompatible with the rules of a modern society and unavoidably brought to crime. So the born to crime in Lombroso was described by abnormal anatomical findings as skull deformities, facial asymmetries, large size ears, prognathism, abnormal teeth, wrinkled skin, long limbs, but also extra-anatomical features, total absence of moral sense, narcissism, cruelty, vindictiveness, excessive impulsiveness. Criminal men were also subjects affected by psychopathological disorders and even epileptics were included in this list of criminals, responsible of atrocious crimes and other violent social acts. The first epileptic subject studied was a nobleman, whose "sadistic quirks" were considered by Lombroso as equivalent to access epileptic; the second man was the Calabrian soldier Salvatore Misdea, who killed some fellow soldiers and upon awakening, after the criminal fact, showed neither complete unconsciousness (as people with epilepsy), nor any remorse (acting as the born to crime). The discussion about the influence of epileptic factor on delinquent gesture moved since the previous decade in these two cases, when scientific analysis more properly the epileptic phenomenon had led to breakthroughs such as disturbing discoveries, both because of the vastness of the medical and pathological horizon, both because of the questionable methods of experimentation. Epilepsy appeared as the explanation of growth arrest in criminals and of romping moral insanity in its episodes ${ }^{3}$. Then, in criminal woman, prostitution was the main criminal aspect, in addition to reduced brain volume, weight and tendency to crime of passion ${ }^{4}$. Cesare Lombroso saw also left-handedness as evidence of a criminal personality. He came to include left-handedness among the somatic stigmata of offenders, having just found a high presence of left-handers in prisons. Only in the 60-70s of last century it has been proven the safety of left-handedness: since the right hemisphere, as well as being appointed to fundamental neurological functions, including the perception of spatial parameters and the summary faculties, is the seat of emotions, imagination and creativity (Crocq, 2013; Kushner, 2013), you find particularly interesting to note that, in general, left-handed people think mental representations rather than concepts and are also often equipped with mnemonic, intuitive and visuo-spatial abilities higher than those of the right-handed subjects (at the popular level, sometimes left-handedness is considered term equivalent to genius by many people, suggestionate by the fact that many famous people were or are left-handed: Aristotele, Charlemagne, Leonardo da Vinci, Joan of Arc, Wolfang Amadeus Mozart, Gandhi, Emmanuel Kant and others). Lombroso, then, played the study of the skull, using measurement parameters, as length, width and depth, filling braincase with lead shot to evaluate capacity (D'Agostino, 2002). Cephalometry represented another instrument to identify crime attitudes so that term of criminal anthropometry was conied. Furthermore, Lombroso's publication activity was very rich, among which, "L'Uomo Delinquente" (The Criminal man) 1876, "Genio e follia» (Genius and Madness) 1877, L'Uomo Bianco e L'Uomo di Colore (White Man and Black man) 1892, "La Donna Criminale« (The Criminal Woman) 1895. He also carried out studies on microcephaly, cretinism and pellagra, physiognomy of anarchists, genius degeneration. Lombroso's theories were most popular at his times, principally in USA, but disapproved in Europe, and Charles Goring, in his work, »The English Convict«, making and elaborating comparisons of physical features between criminals and no criminals, did not find significant statistic differences. In Italy the case of a Calabrian man supposed as brigand, Giuseppe Villella, whose autopsy was performed by Lombroso, induced the scientist to postulate, in 1876, that congenital fusion of the occipital bone with atlas and the absence of internal occipital crest was a phenotypic sign of the criminal man. These morphoanthropological theories, in which the external appearance is related to crime, were postulated in the second half of 1800 , when studies on nervous system obtained relevant results, from neuron theory with the discovery of electric origin of nerve impulse to the mechanisms of motor and sensorial pathways until the cortex functions. Gall (1758-1828) was the first to support the concept of cortex as most elevated level of the nervous system, from which arises the white matter. Nevertheless, he correlated all the cortical functions to skull capacity, that was the fact that the brain tissue consistency was in strict relationship with morphology of the skull. Flourens (1794-1867) deepened the postulate of Gall, working on experimental animal models and attributing to cerebral cortex superior functions as opinion faculty, will acts, consciousness. Paul Broca (1824-1880) identified, after an autoptical examination, the centre of motor language in the third left convolution of left frontal lobe. J. H. Jackson (1835-1911) then offered an olistic vision of nervous system, where both cortical and subcortical structures worked together, playing the role of control and regulation, respectively, of more elevated and primary brain activities. Korbinian Brodmann (18681918) even divided the cerebral cortex in 52 regions topographically and functionally different, numbering them, after being observed by light microscopy. So, it was created a mapping of these regions, through a comparison with cortical areas of monkeys. Based on this, different cortical functions, primary as pain and somatic sensitivity, the vision, the hearing, movement, language, so as the identification of more developed areas, such as the association areas, were a scientific discovery of great value, still used in the literature and in the clinic, from neurologists, neurophysiologists, anatomists, continuously updated, especially thanks to the studies done with help of tests such as f MRI. At successive times, Heinrich Kluver (1897-1979) and Paul Bucy (1904-1992) noted 
that bilateral lesions of temporal lobe, involving amygdale and hippocampus, in Rhesus monkey caused a series of symptoms as hyperphagia, hypersexuality, hyperorality and absence of fear. There is still the case of Phineas Gage (1823-1860), an American railway construction worker, who suffered by an incident, in which an iron bar passed through his head, provoking a damage in frontal lobe cortex. He survived but reported dramatic changes of personality, social behavior and mood disorders as hyperanxiety or aggressiveness. Today special attention is given to crime genetics: constantly advancing studies open up new and interesting perspectives about the possible influence of genotype on the genesis of criminal behavior. It was coined the term "the warrior gene" which correlates the violent and antisocial behavior at low activity allele of MAO-A gene (Monoaminoxidase gene A). The genetic cause of crime was already alleged in the years $60 \mathrm{~s}-70 \mathrm{~s}$, when it was postulated that men who carried an extra Y chromosome, the so-called XYY syndrome, were thought to be at increased risk of violence, a subsequently disproven contention. In 1993, Brunner described the case of a Dutch kindred, in which several males exhibited borderline mental retardation and abnormal behavior, including disturbed regulation of impulsive aggression. They were found to have a complete absence of activity of the enzyme monoamine oxidase A (MAO-A), which metabolizes several key monoamine neurotransmitters. Genetic analysis revealed that the affected men carried a mutation on their $\mathrm{X}$ chromosome in the gene that codes for MAO-A, that rendered the enzyme inactive. The authors suggested that genetic defects in neurotransmitter metabolism may affect aggressive behavior. Exploring the interactions of the participants' genetic endowments with their environmental circumstances, the researchers looked at the impact of maltreatment between the ages of three and 11 on later antisocial propensities of participants with either high or low MAO-A activity. They found that manifestations of antisocial behavior were significantly increased in the group that had both low MAO-A activity and a history of severe maltreatment. In contrast, for participants with high levels of MAO-A, even in the presence of maltreatment, the increase in antisocial activity was much less significant. The overall impact of this gene-environment interaction was evidenced by the fact that the 12 percent of the study group that had both low MAO-A and maltreatment, valued about 44 percent of the convictions for violent crime. Eighty-five percent of the males, with both risk factors, developed some form of antisocial behavior. Other studies proposed that hormonal activity (high testosterone levels) may be responsible for both low MAO-A activity and violence. Another study later showed that functional connectivity between the ventro-medial prefrontal cortex (vmPFC) and the amygdala, belonging to the limbic lobe, was increased only in males with the low MAO-A prefrontal gene. In addition, that study found that when performing an emotional face matching task, low MAO-A activity males showed increased activation of the amygdala and decreased activation of the vmPFC, compared to control subjects. Also a link between the crime and the dopaminergic and serotonergic system was found, as evidenced by studies on alcohol intoxication, related to lower thresholds of aggressive behaviors. In this association study of two independent samples, a number of candidate gene variants $(5 \mathrm{HT} 2 \mathrm{~A}$ T102C, 5-HTTLPR, DRD Ins-141Del, DAT1 VNTR) were related to violent criminal behavior and alcohol-related aggressive traits. Finally, the influence of the environment on crime: poverty, malnutrition, alcoholism, drug abuse, family and social degraded context, but also, though less frequent, social and family conditions wealthy, extremist political beliefs, mistreatment, torture, especially in the child and adolescent ages, are all factors, along with many others, which can contribute, together with the individual genotype, to generate violence and criminal behavior. This historical review offers some reflections : during 1800 s, neurophysiological knowledge was at the heights and the second half of the century demonstrated the explanation of many cerebral events. In short, the development of neurophysiology enriched in those years the cultural baggage of neuroscientists, through empiric results, successively proved by experimental studies. The era in which Lombroso lived was yet seen by neuroscientists as a fecund period in which cerebral functions were studied and new knowledge reported. The normality, as soon as the abnormality of brain functions, all were the result of localizing and functioning of anatomical structures. Then, the acts, mood, personality in human, arise from anatomic neurological sites and pathways, that can work normally or be altered. "Mens agitat molem « is an ancient Latin allocution, considering psychic influence of mind over social life and, on the other hand, actually it is known that mental processes depend on neuronal functions, which are a set of neurotransmitter and morpho-structural mechanisms of the brain (Liberini, 2000). So, psychopathologic events are also related to brain alterations, which have various etiopathogenesis, for example, neoplastic, vascular, inflammatory, traumatic, especially affecting some cortical regions, as prefrontal cortex and temporal cortex. Prefrontal cortex is the area of consciousness, voluntary mechanism, ideation and planning, reasoned acts. Temporal lobe, particularly limbic cortex, is the site of memory, emotional processes, responsible of instinctual, primitive acts, as aggressiveness, fear, anger, wrath, insensitivity, indifference. Furthermore, prefrontal cortex and limbic cortex lobe are balanced structures that work in antagonism, the reason and the emotion, whose imbalance may induce the so-called sociopathy, characterized by the pathological contempt of the subject to the rules and laws of society, impulsive behavior, inability to take responsibility and indifference towards the feelings of others, virtually responsible of criminal acts.

\section{Conclusions}

Definitely, the morphological aspects in humans have not been relevance for the crime, what matters is what 
there is inside, into the brain, not outside. Lombroso's theories instead emphasized the morphology throughout the criminal human body, whose various stigmata, like those described above, are the expression. Genotype as environmental influence and organic, internal and external brain factors, may be responsible for the crime, that are ugly, dirty, bad or beautiful, clean and good, that is the only way the human neurophysiology will not ignored.

\section{R E F E R E N C E S}

1. LIDBERG L, Lombroso introduced a new perspective on forensic psychiatry: focus on the criminal, not the crime. Lakartidningen. 2000 Sep 13;97(37):4031 - 2. CROCQ M, Milestones in the history of personality disorders. Dialogues Clin Neurosci. 2013 June; 15(2): 147-153 - 3. GRANIERI E, FAZIO P, The Lombrosian prejudice in medicine. The case of epilepsy. Epileptic psychosis. Epilepsy and aggressiveness. Neurol Sci. 2012 Feb;33(1):173-92. - 4. KUHAR M, FATOVIĆ-FERENČIĆ S, Prostitutes and criminals: beginnings of eugenics in Croatia in the works of Fran Gundrum from Oriovac (1856-1919). Croat Med J. 2012 April; 53(2):

\section{Acknowledgements}

This research did not receive any specific grant from funding agencies in the public, commercial, or not-forprofit sectors.

The authors declare that they have no competing interests or financial support.

All authors read and approved the final manuscript.

DC provided language help, ADT and RM provided writing assistance and AL provided proof reading the article.

\section{Chirchiglia}

Department of Neurosurgery, University of Catanzaro "Magna Graecia ", Viale Europa-Loc. Germaneto (88100), Catanzaro, Italy

e-mail: chirchiglia@unicz.it

\begin{abstract}
185-197. - 5. KUSHNER HI, Deficit or creativity: Cesare Lombroso, Robert Hertz and the meaning of left-handedness. Laterality. 2013;18(4):416-36. - 6. D'AGOSTINO P, Craniums, criminals, and the "cursed race«: Italian anthropology in American racial thought, 18611924. Comp Stud Soc Hist. 2002;44(2):319-43. - 7. MONACO F, MULA M, Cesare Lombroso and epilepsy 100 years later: an unabridged report of his original transactions. Epilepsia. 2011 Apr;52(4):679-88. - 8. LIBERINI P, SPANO P, From the mind to the brain: an unusual pathway. J Hist Neurosci. 2000 Apr;9(1):41-5.
\end{abstract}

\section{LOMBROSOV ROĐEN ZA ZLOČIN, MORPHOANTROPOLOGIJA I ZANEMARENA LJUDSKA NEURO- FIZIOLOGIJE: KRITIČKI OSVRT NA POVIJESNI KONTEKST}

\section{S A Ž E T A K}

Lombrosove teorije su 1800. upriličile snažan šok u međunarodnoj znanstvenoj zajednici, što se tiče odnosa između ljudske morfologije i sklonosti kriminalu. Slijedili su ih posebno iz Europe, a danas se o njima još uvijek raspravlja, no u tom stoljeću su se obogatila istraživanja o ljudskoj neurofiziologije, koji će vrijediti do našeg vremena i oštro su opovrgnuli Lombroso koncepte. Ukratko, ignorirajući neurofiziologiju, na štetu hipoteze koje raspravlja sklonost kriminalu kao izraz fizičkih osobina pojedinca, cijelog tijela, lica, udova, uši i oblika lubanje. U ovom pregledu, izrađene su i neke kritičke primjedbe o Lombrosovom konceptu, na atavizam t.j. ljude koje se smatra inferiornim na osnovu njihovog fizičkog izgleda, drugim riječima što se zove morphoantropologija. U isto vrijeme, ovaj rad ističe, umjesto na "važnost neurofiziološkim aspekata individualni teži zločin, koje su temelj abnormalnih djela protiv društva", a koje se odnose na disfunkciju u određenim područjima mozga, kao što je frontalni korteks i limbički kora, pod utjecajem genotipa i okolišnih čimbenika. 